\title{
Hypernatraemia and uraemia in unexpected death in infancy
}

\author{
JOHN L. EMERY, P. G. F. SWIFT, and E. WORTHY \\ From the Department of Pathology, Children's Hospital, Sheffield
}

\begin{abstract}
Emery, J. L., Swift, P. G. F., and Worthy, E. (1974). Archives of Disease in Childhood, 49, 686. Hypernatraemia and uraemia in unexpected death in infancy. The electrolyte concentration of the vitreous humour of the eye in a consecutive series of 40 infants dying unexpectedly at home was measured. In 25 of these infants no morbid anatomical cause of death was found, but in half of these infants analysis of the vitreous humour indicated the presence of hypernatraemia, either with or without uraemia. High solute feeding and water deficiency could therefore have been a major factor in the death of these infants.

Estimation of the vitreous electrolytes is an essential part of examination of children falling within the 'cot death' group.
\end{abstract}

At the present time approximately half of the children who die between the ages of 2 weeks and 2 years do so at home and unexpectedly (Emery, 1973). These unexpected deaths in infancy, 'cot deaths', have been the subject of much study (Camps and Carpenter, 1972; Wedgwood and Benditt, 1966; Bergman, Beckwith, and Ray, 1970), with the emphasis mainly on epidemiology, largely because of the paucity of morbid anatomical findings (Froggatt, Lynas, and Mackenzie, 1971). Of children found unexpectedly dead, even after the most critical studies now available, a minority (about $5 \%$ ) show no evidence of any short- or long-standing disease or gross derangement, though a majority show varying degrees of minor change the importance of which is difficult to assess. This applies not only to children showing evidence of virus infection in the respiratory tract, as identified by Gardner and his colleagues (Gardner, 1968; Ferris et al., 1973) but also to lesions of the heart, larynx, and intestinal tract. While it is possible to postulate many mechanisms for the lesions causing death, it has always been realized that the pathways leading to death are almost certainly to be found in terms of biochemical changes and probably at a cellular level. Chemical data on children found unexpectedly dead have been reported, but apart from one study (Sturner and Dempsey, 1973), have been largely confined to the blood and CSF.

Received 19 February 1974.
The vitreous humour forms an isolated pool of fluid which retains after death some of its antemortem biochemical characteristics. It has been used by forensic pathologists in attempts to determine the time of death of adults (Adelson et al., 1963; Sturner and Gantner, 1964) or to diagnose uraemia or alcohol ingestion (Coe and Sherman, 1970). We recently studied the vitreous humour in children who had died in hospital and related the composition of the fluid after death to the plasma chemistry present before death, which indicated that the levels of urea and sodium in the vitreous humour could be used as indicators of the terminal state of the child (Swift, Worthy, and Emery, 1974).

The importance of this in the child found unexpectedly dead has been stimulated by the recent clinical appreciation that some children, in the presence of apparently mild disease, are liable to become uraemic and hypernatraemic, particularly if accompanied by high solute feeding (Taitz and Byers, 1972). Such children frequently do not show the usual signs of dehydration, and if they die show no specific histopathology. We wondered how many children found unexpectedly dead at home might be in this state. Thus, an investigation of the vitreous humour from children coming to necropsy and who were found unexpectedly dead forms the basis of the present study.

\section{Material and methods}

A sequential series of 40 infants who had died 
unexpectedly was studied. All died in the Sheffield region and were referred to the Pathology Department of the Children's Hospital in Sheffield for necropsy, which was performed by one of us (J.L.E.).

As soon as possible after arrival of the body in the mortuary vitreous humour was gently aspirated from the eyeball from the direction of the outer canthus through a disposable 17-gauge needle. Before final removal of the body from the mortuary, a second sample was often obtained from the other eye. Fluid aspirated was replaced by water to maintain turgidity. It was usually possible to aspirate 50-800 $\mu$ l fluid. This was subjected to microchemical analysis as follows. Sodium and potassium by integrating flame photometer (EEL.227); magnesium and calcium by atomic absorption spectrophotometer (EEL.140); urea by the urease-Berthelot method, and glucose by a glucose-oxidase method.

As the exact time of death was usually not known, the time of death was then estimated to be half way between the time when the child was last seen alive and the time found dead. The post-mortem interval before taking the first vitreous specimen varied from 1 hour to 48 hours. The average interval between the last time seen alive and the time found dead was 5.5 hours in 18 cases. In 4 children death was witnessed.

Following necropsy the anatomical findings were graded according to the following classification (Emery, 1973).

(A) The child had a well recognized condition of long standing, e.g. congenital heart disease, Down's syndrome.

(B) Necropsy revealed a widely accepted cause of severe disease or death, e.g. meningococcaemia or pneumonia.

(C) Lesions revealed at necropsy would only be expected to cause minor recoverable disease, e.g. bronchitis.

(D1) No evidence of definite disease revealed, but a more specific indication of a general disturbance in metabolism.

(D2) No finding of pathological disturbance.

Information regarding the health of the infants before death was obtained from several sources: a questionnaire completed by a woman police officer who visited the home shortly after the child was found dead, the records of a research social worker who visited 3 weeks later, health visitors, and the family doctor.

\section{Results}

Table I gives the clinical and pathological details of each case.

Sodium. In our laboratory the upper limit of normal for plasma sodium in the first year after birth is $141 \mathrm{mEq} / \mathrm{l}$. Vitreous sodium levels in the initial specimens varied from 128 to $164 \mathrm{mEq} / \mathrm{l}$. Of the 40 cases, 7 had sodium values of more then 150 and a further 10 were in excess of $142 \mathrm{mEq} / \mathrm{l}$. Second specimens were obtained in 20 of the first 28 cases.

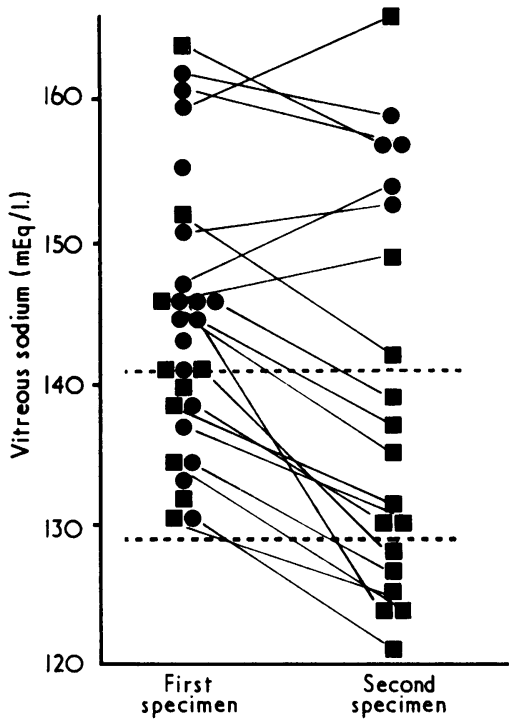

FIG. 1.-Vitreous sodium levels in the first 28 cases studied. 20 cases had 2 separate samples taken at different times after death. samples taken within 24 hours of death; taken after 24 hours. Dotted lines indicate the normal range of plasma sodium.

They showed a fall in sodium level in 16 and a rise in 4. These results are illustrated in Fig. 1.

All cases with an initial vitreous level below 141 $\mathrm{mEq} / \mathrm{l}$. showed a subsequent decrease in concentration in the second specimen. The 4 cases which exhibited a rise in concentration had initial levels greater than 145 . In 2 cases where the initial sodium levels were abnormally high (145 and 146), the second specimens taken within 30 hours of death fell within normal limits. However, in no cases did values change in the reverse direction from normal to above normal.

Urea. Vitreous urea levels in the initial specimens ranged from 23 to $196 \mathrm{mg} / 100 \mathrm{ml}$. In the 40 cases, 6 had urea concentrations of more than $100 \mathrm{mg} / 100 \mathrm{ml}$ and a further 10 were in excess of 60 . ( 3 cases had urea levels above $100 \mathrm{mg} / 100 \mathrm{ml}$ and sodium levels above $150 \mathrm{mEq} / 1$.)

Second specimens were obtained in 19 of the first 28 cases studied and in 16 of these the concentration had increased (Fig. 2). If the upper limit of normal for urea concentration were taken as $60 \mathrm{mg} / 100 \mathrm{ml}, 3$ cases in which initial specimens fell within this boundary had second specimens with levels greater than 60 . 
Clinical details and pathology and biochemistry of vitreous

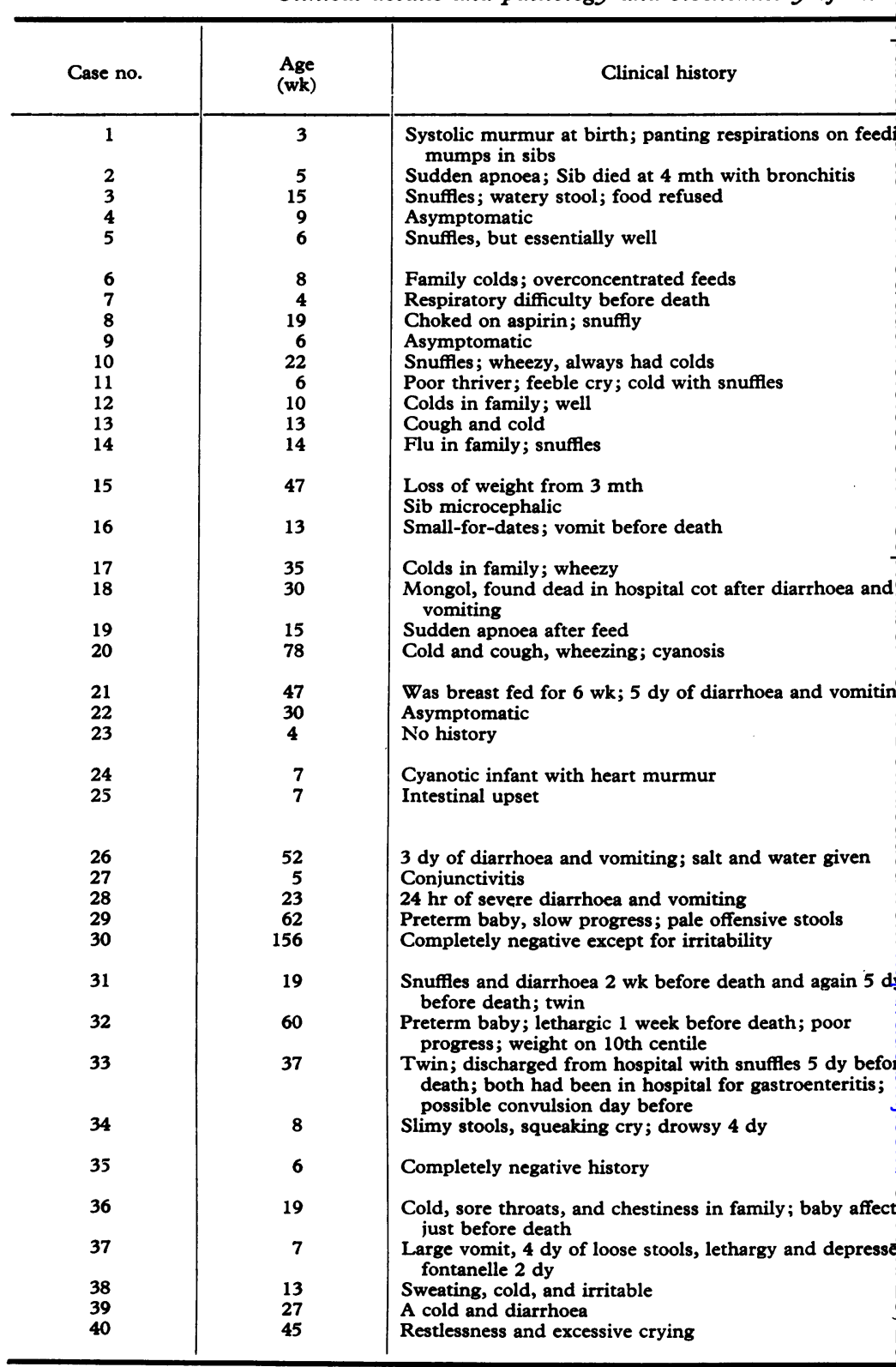

^For classification A, B, or C, see text.

Magnesium. Vitreous magnesium levels in 27 vitreous specimens varied from $2 \cdot 8$ to $5 \cdot 8 \mathrm{mg} / 100$ $\mathrm{ml}$ with a mean of $3.5 \mathrm{mg} / 100 \mathrm{ml}$. In a larger series of vitreous humour chemistry in children dying with other recognized disorders, the magnesium levels varied from $2 \cdot 1$ tu $6 \cdot 0 \mathrm{mg} / 100 \mathrm{ml}$. There appeared to be a marked age dependence. $78 \%(21 / 27)$ of the levels for the unexpected death series fell just below the age-related curve for all children studied and the remaining 6 values were 
humour in 45 children found unexpectedly dead

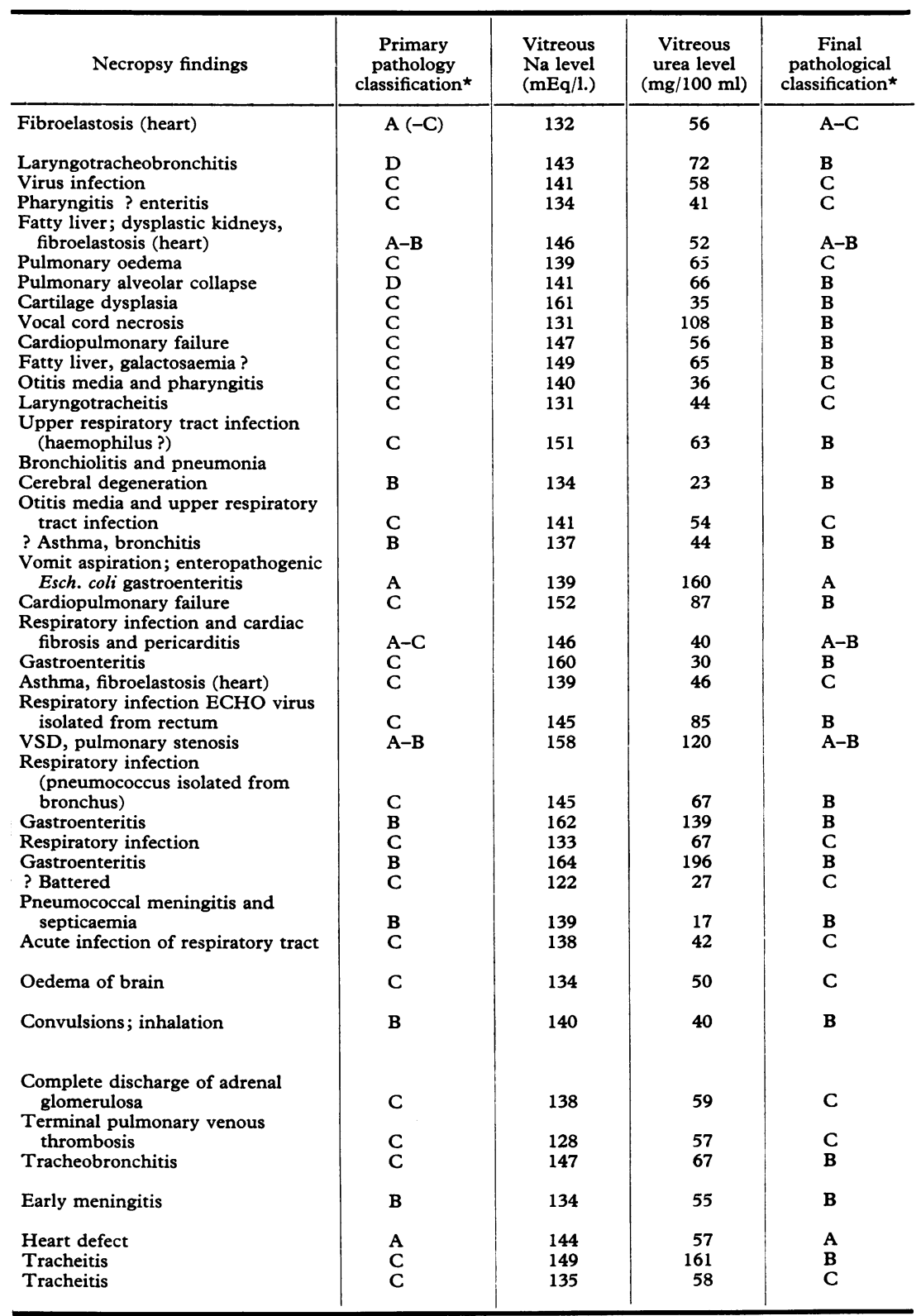

above the curve. 5 of the 6 with high magnesium values also had other abnormal electrolyte concentrations.

Calcium. Calcium levels in 17 vitreous specimens ranged from $6 \cdot 3$ to $8 \cdot 3 \mathrm{mg} / 100 \mathrm{ml}$ in all but one case, where there was a high level of $10 \cdot 1$ $\mathrm{mg} / 100 \mathrm{ml}$. There was no age dependence and no consistent rise or fall in calcium concentration with increasing time post mortem. 


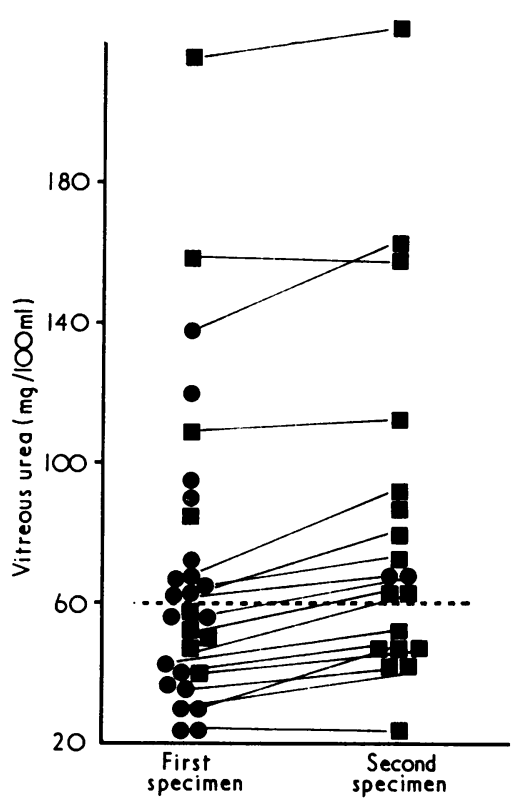

FIG. 2.-Vitreous urea levels in the first 28 cases studied. 19 cases had 2 separate samples taken at different times after death. samples taken within 24 hours of death; taken after 24 hours. Dotted lines indicate the normal upper range of plasma urea.

Glucose. Vitreous glucose was measured in only 8 cases. The results are shown in Table II. In 4 cases where a second sample was taken, the glucose concentration had diminished, the rate of fall varying from 0.4 to $1.0 \mathrm{mg} / 100 \mathrm{ml}$ per hour.

\section{Discussion}

Hypotheses invoking a biochemical cause for 'cot deaths' are legion, but biochemical studies are few. This may be partly explained by the difficulties of obtaining suitable necropsy materials for analysis,

TABLE II

Glucose levels of vitreous humour in 8 children found unexpectedly dead

\begin{tabular}{c|c|c|c|c}
\hline $\begin{array}{c}\text { Case } \\
\text { no. }\end{array}$ & $\begin{array}{c}\text { First specimen } \\
\text { vitreous glucose } \\
(\mathrm{mg} / 100 \mathrm{ml})\end{array}$ & $\begin{array}{c}\text { Hours } \\
\text { after } \\
\text { death }\end{array}$ & $\begin{array}{c}\text { Second specimen } \\
\text { vitreous glucose } \\
(\mathrm{mg} / 100 \mathrm{ml})\end{array}$ & $\begin{array}{c}\text { Hours } \\
\text { after } \\
\text { death }\end{array}$ \\
\hline 21 & 268 & 3 & 256 & 26 \\
22 & 53 & 1 & 23 & 50 \\
23 & $<10$ & 7 & - & - \\
24 & $<10$ & -24 & 111 & 27 \\
25 & 132 & 2 & 28 & 48 \\
26 & 53 & -28 & $<10$ & 48 \\
27 & -10 & 38 & & 54 \\
\hline
\end{tabular}

while few of the necropsies are carried out in children's hospital mortuaries where biochemistry on small volumes of fluid is available. Vitreous humour appears to be a suitable fluid medium on which to investigate 'cot death' chemistry. It is uncontaminated by blood, and its chemistry reflects that of aqueous humour and plasma (Pirie and van Heyningen, 1956; Davson, 1972). Its chemical composition changes less after death than blood or CSF (Naumann, 1959), and even in small infants it is easy to obtain.

In a large study of cot deaths in Northern Ireland, plasma urea was measured at necropsy in 100 cases. One-third showed levels in excess of $100 \mathrm{mg} / 100 \mathrm{ml}$ (Marshall, 1970). In the same survey plasma amino acid chromatograms, immunoglobulins, and blood groups were analysed with no conclusive evidence of abnormality (Froggatt, 1970). In 30 cases of 'crib deaths' in an American series, blood urea nitrogen was said to be 'somewhat elevated' (Stowens, Callahan, and Clay, 1966). A rise in blood urea in 12 cot deaths compared with 47 controls was reported by McGaffey (1970), who suggested that severe metabolic crises were present at the time of death including acidosis, hyponatraemia, uraemia, and raised enzymes. The relevance of these findings is uncertain because plasma chemistry alters rapidly after death (Naumann, 1950; Hodgkinson and Hambleton, 1969) and the length of time after death is not stated.

Sturner and Dempsey (1973) have reported analyses of vitreous humour sampled within 24 hours of death in 67 infants dying under the age of 1 year. In 12 who died from asphyxia they found none with abnormal electrolyte or urea levels. In 33 in whom they found otherwise adequate pathological causes of death, 11 had sodium concentrations above their normal range and 13 had raised urea levels, 9 of which coincided with the high sodium values. In 22 with undetermined causes of death, 6 showed an individual or combined decrease in sodium, chloride, and potassium. None of this group showed hypernatraemia, but their criteria for classifying the cause of death are not clear, and prevent any case comparison with any of our own.

In the present series, vitreous humour was sampled in all cases within $\mathbf{4 8}$ hours of death and in most cases within 24 hours. $18 \%$ of the cases had vitreous sodium levels in excess of $150 \mathrm{mEq} / \mathrm{l}$., suggesting severe hypernatraemia at the time of death. In a further $25 \%$ the sodium concentration was more than $142 \mathrm{mEq} / 1$.

Grossly raised urea levels (i.e. $100 \mathrm{mg} / 100 \mathrm{ml}$ ) occurred in 6 , and in a further 10 the urea concentration was greater than $60 \mathrm{mg} / 100 \mathrm{ml}$. Mildly 
uraemic figures were possibly associated with agonal renal failure, but the cases in which the urea concentration was grossly raised suggests protracted nitrogen retention.

Three cases had a vitreous sodium concentration of more than $150 \mathrm{mEq} / \mathrm{l}$. in combination with a urea concentration of more than $100 \mathrm{mg} / 100 \mathrm{ml}$. One was a 7-week-old infant with a congenital heart lesion in whom no electrolyte disturbance was suspected. Another was a child aged $2 \frac{1}{2}$ months who had diarrhoea and vomiting for 3 days. Antibiotics with a salt-water-glucose regimen was instituted for $\mathbf{4 8}$ hours before his death on the way to hospital. The third, aged 5 months, had diarrhoea for 24 hours, an appointment was unobtainable at the doctor's surgery and the child died suddenly at home. A further child with gastrointestinal symptoms in this series had a normal urea concentration but a sodium level of $160 \mathrm{mEq} / \mathrm{l}$.

The serious sequelae of hypernatraemic and hyperosmolar dehydration have become recognized in recent years (Harrison and Finberg, 1959; Macaulay and Watson, 1967); and many infants have been found to be markedly hypernatraemic without obvious clinical signs of dehydration. There is also a significant proportion of asymptomatic bottle-fed infants whose plasma osmolality is above the range of normal (Davies, 1973).

It is therefore important that of the 25 children in the present series of unexpected deaths that fall into the largely unexplained category at necropsy (groups C and D), 12 had vitreous sodium and urea concentrations above normally accepted plasma levels. There were 5 infants within this group who had no reported symptoms before death; necropsy revealed nothing significantly abnormal and all 5 had either a vitreous sodium above $150 \mathrm{mEq} / 1$. or urea above 100 $\mathrm{mg} / 100 \mathrm{ml}$. But in these 5 the history had not been taken by a paediatrician or a skilled social worker. Thus, it seems that half of the infants who died with what would, in any company, be accepted as being cases of 'unexpected death in infancy syndrome' were in severe electrolyte imbalance at the time of death. While many possible causes of this chemical abnormality exist, the findings could well be due to infants being fed with 'thickened' hyperosmolar milk and solids at the time of a minor infection (Finberg, 1969).

Our findings in relation to magnesium, calcium, and glucose are less clear cut and clearly require further study. Caddell's (1972) suggestion that unexpected death in infancy might be triggered by magnesium deficiency gains no support from our findings to date.

The relation between ante-mortem plasma calcium and post-mortem vitreous calcium remains obscure, but in our small series the vitreous calcium, though lower than normally accepted plasma levels, was similar to levels measured in children dying from other causes.

The possible role of hypoglycaemia in unexpected child death should not be forgotten in view of Porter's carefully argued hypothesis (Camps and Carpenter, 1972). Vitreous glucose concentration in some of our cases was extremely low, but these samples were often taken more than 8 hours after death. Post-mortem glycolysis reduces vitreous glucose and values do not consistently reflect ante-mortem plasma levels. However, it is of interest that 1 child showed a high vitreous glucose, $268 \mathrm{mg} / 100 \mathrm{ml}$ (without ketones) 3 hours after death in association with the picture of severe hypernatraemia. Hyperglycaemia is a recognized feature in the acutely ill child with the hypertonic dehydration syndrome (Heggarty, Trindade, and Bryan, 1973). The vitreous glucose in 1 case was less than $10 \mathrm{mg} / 100 \mathrm{ml} 7$ hours after death, suggestive of significant hypoglycaemia, but further measurements of vitreous glucose shortly after death are required before this parameter can be evaluated.

To define the cause of death at necropsy in children is not simple, as the extent of a morbid anatomical lesion frequently is unrelated to its lethal properties. Some children survive in whom extensive areas of lung are the site of necrosis and pneumonia, while others die with extremely small lesions, and the same applies to degrees of hypernatraemia and uraemia, as judged by the levels of sodium and urea in sampled fluids. It is for these reasons that we adopted the classification of groups of findings, A, B, C, D, described above, in analysing child deaths. In Table III the grading of the present sequential series of children dying unexpectedly has been listed in these four categories. The disease category based on the complete necropsy including histology and bacteriology is compared with the assessment of the case including the biochemistry of the vitreous. Transferring a case from category $\mathrm{C}$ to $\mathrm{B}$ does not necessarily explain its death, as indeed placing a child in category $B$ does not explain its death. It must be realized that we frequently do not know the precise cause of death in many natural deaths in hospital. However, a child with evidence of mild tracheobronchitis or gastroenteritis who is hypernatraemic and uraemic, is more likely to be ill and to require treatment than a child with a mild tracheitis with normal electrolytes.

Knowledge of the vitreous biochemistry has greatly diminished the number of children who were 


\section{TABLE III}

Final necropsy grading of a sequential series of 40 infants found unexpectedly dead, based on histology combined with results of vitreous chemistry

\begin{tabular}{l|c|c}
\hline $\begin{array}{c}\text { Classification of } \\
\text { necropsy findings }\end{array}$ & $\begin{array}{c}\text { Gross and } \\
\text { histology }\end{array}$ & $\begin{array}{c}\text { Histology including } \\
\text { biochemistry of vitreous }\end{array}$ \\
\hline $\begin{array}{l}\text { A Child with gross } \\
\text { congenital deformity } \\
\text { with B (below) } \\
\text { with C (below) }\end{array}$ & 2 & 2 \\
B Evidence of acute & 2 & 3 \\
$\begin{array}{l}\text { disease sufficient } \\
\text { to cause severe } \\
\text { symptoms }\end{array}$ & 2 & 1 \\
C Evidence of minor & 7 & $2 J$ \\
symptom-producing & 25 & 14 \\
state & & \\
D No evidence of A, & 2 & 0 \\
B, or C & & \\
\hline Total & 40 & 40 \\
\hline
\end{tabular}

apparently absolutely fit at the time of death. What is more important is that we now have a situation where one-half of the children that are found unexpectedly dead out of hospital are in category B, i.e. having evidence of a disease state that if diagnosed would be amenable to some form of treatment. This does not mean that death in these children was always preventible, but if the diseases we have diagnosed contribute to death by instigating some unknown final common pathways, then that aspect at least was amenable to improvement.

The present study has indicated two points. First, that hypernatraemia appears to be present in about half of those children falling into the 'cot death' category in whom no adequate morbid anatomical cause of death is found. While hypernatraemia and uraemia are unlikely to be the principal cause of death in these children, when present it is likely to be an important factor. The hypernatraemia and uraemia is often due to the children being fed overconcentrated foods, a situation that needs to be pursued actively in any attempt to diminish the incidence of these deaths. The second point concerns necropsy of infants found dead; estimations of the vitreous humour electrolytes should be an essential part of the study in all such deaths.

We acknowledge the assistance of the Foundation for the Study of Infant Death.

\section{REFERENCES}

Adelson, L., Sunshine, I., Rushforth, N. B., and Markoff, M. (1963). Vitreous potassium concentration as an indicator of postmortem interval. Fournal of Forensic Sciences, 8, 503.

Bergman, A. B., Beckwith, J. B., and Ray, C. G. (1970). Sudden Infant Death Syndrome. University of Washington Press, Seattle and London.
Caddell, J. L. (1972). Magnesium deprivation in sudden unexpected infant death. Lancet, $2,258$.

Camps, F. E., and Carpenter, R. G. (1972). Sudden and Unexpected Deaths in Infancy (Cot Deaths). Sir Samuel Bedson Symposium, Cambridge, 1972, p. 74 . Wright, Bristol.

Coe, J. I., and Sherman, R. E. (1970). Comparative study of postmortem vitreous humor and blood alcohol. fournal of Forensic Sciences, 15, 185.

Davies, D. P. (1973). Plasma osmolality and feeding practices of healthy infants in first three months of life. British Medical Fournal, 2, 340.

Davson, H. (1972). Physiology of the Eye, 3rd ed., p. 32. Churchill Livingstone, Edinburgh and London.

Emery, J. L. (1973). Unexpected deaths in infants. Nursing Times, April 12th, p. 474.

Ferris, J. A. J., Aherne, W. A., Locke, W. S., McQuillin, J., and Gardner, P. S. (1973). Sudden and unexpected deaths in infants : histology and virology. British Medical fournal, 2, 439.

Finberg, L. (1969). Year Book of Pediatrics, p. $49 . \quad$ Ed. by S. S. Gellis. Year Book Medical Publishers, Chicago.

Froggatt, P. (1970). Sudden Infant Death Syndrome, p. $25 . \quad$ Ed. by A. B. Bergman, J. B. Beckwith, and C. G. Ray. University of Washington Press, Seattle and London.

Froggatt, P., Lynas, M. A., and Mackenzie, G. (1971). Epidemiology of sudden unexpected death in infants (cot death) in Northern Ireland. Fournal of Preventive and Social Medicine, $25,119$.

Gardner, P. S. (1968). Virus infections and respiratory disease of chilclhood. Archives of Eisease in Childhood, 43, 629.

Harrison, H. E., and Finberg, L. (1959). Hypernatremic dehydration. Pediatric Clinics of North America, 6, 193.

Heggarty, H., Trindade, P., and Bryan, E. M. (1973). Hyperglycalemia in hyperosmolar dehydration. Archives of Disease in Childhood, 48, 740 .

Hodgkinson, A., and Hambleton, J. (1969). Elevation of serum calcium concentration and changes in other blood parameters after death. Fournal of Surgical Research, 9, 567.

Macaulay, D., and Watson, M. (1967). Hypernatraemia in infants as a cause of brain damage. Archives of Disease in Childhood, 42, 485.

McGaffey, H. L. (1970). Crib death: metabolic disturbances reflected in laboratory studies. (Abst.) American fournal of Clinical Pathology, 54, 270.

Marshall, T. K. (1970). The Northern Ireland study: pathology findings. In Sudden Infant Death Syndrome, p. 116. Ed. by A. B. Bergman, J. B. Beckwith, and C. G. Ray. University of Washington Press, Seattle and London.

Naumann, H. N. (1950). Studies on postmortem chemistry. American fournal of Clinical Pathology, 20, 314.

Naumann, H. N. (1959). Postmortem chemistry of the vitreous body in man. Archives of Ophthalmology, 62, 356.

Pirie, A., and van Heyningen, R. (1956). Biochemistry of the Eye, p. 242. Blackwell, Oxford.

Stowens, D., Callahan, E. L., and Clay, J. (1966). Sudden unexpected death in infancy: a new hypothesis of cause. Clinical Pediatrics, 5, 243.

Sturner, W. Q., and Dempsey, J. L. (1973). Sudden infant death: chemical analysis of vitreous humor. Fournal of Forensic Sciences, 18, 12.

Sturner, W. Q., and Gantner, G. E. (1964). The postmortem interval: a study of potassium in the vitreous humor. American Fournal of Clinical Pathology, 42, 137.

Swift, P. G. F., Worthy, E., and Emery, J. L. (1974). Biochemical state of the vitreous humour of infants at necropsy. Archives of Disease in Childhood, 49, 680.

Taitz, L. S., and Byers, H. D. (1972). High calorie/osmolar feeding and hypertonic dehydration. Archives of Disease in Childhood, 47, 257.

Wedgwood, R. J., and Benditt, F. P. (1966). Sudden death in infants. In Proceedings of the Conference of Causes of the Sudden Death in Infants, September 1963, Seattle, Washington. Public Health Service Publication No. 1412, Department of Health, Education and Welfare, Washington, D.C.

Correspondence to Professor J. L. Emery, Department of Pathology, The Children's Hospital, Sheffield S10 2TH. 